\title{
Responses of leaf morphology, NSCs contents and C:N:P stoichiometry of Cunninghamia lanceolata and Schima superba to shading
}

Qingqing Liu ${ }^{1,2}$, Zhijun Huang ${ }^{1,2}$, Zhengning Wang ${ }^{1,2}$, Yanfang Chen ${ }^{1,2}$, Zhumei Wen ${ }^{1,2}$, Bo Liu ${ }^{1,2^{*}}$ and Mulualem Tigabu ${ }^{1,3^{*}}$ (D)

\begin{abstract}
Background: The non-structural carbohydrates (NSCs), carbon (C), nitrogen (N), and phosphorus (P) are important energy source or nutrients for all plant growth and metabolism. To persist in shaded understory, saplings have to maintain the dynamic balance of carbon and nutrients, such as leaf NSCs, C, N and P. To improve understanding of the nutrient utilization strategies between shade-tolerant and shade-intolerant species, we therefore compared the leaf NSCs, C, N, P in response to shade between seedlings of shade-tolerant Schima superba and shade-intolerant Cunninghamia lanceolate. Shading treatments were created with five levels $(0,40,60,85,95 \%$ shading degree) to determine the effect of shade on leaf NSCs contents and C:N:P stoichiometry characteristics.

Results: Mean leaf area was significantly larger under $60 \%$ shading degree for C. lanceolata while maximum mean leaf area was observed under $85 \%$ shading degree for S. superba seedlings, whereas leaf mass per area decreased consistently with increasing shading degree in both species. In general, both species showed decreasing NSC, soluble sugar and starch contents with increasing shading degree. However shade-tolerant S. superba seedlings exhibited higher NSC, soluble sugar and starch content than shade-intolerant C. lanceolate. The soluble sugar/starch ratio of C. lanceolate decreased with increasing shading degree, whereas that of S. superb remained stable. Leaf C:N ratio decreased while N:P ratio increased with increasing shading degree; leaf C:P ratio was highest in 60\% shading degree for C. lanceolata and in 40\% shading degree for S. superba.

Conclusion: S. superba is better adapted to low light condition than C. lanceolata through enlarged leaf area and increased carbohydrate reserves that allow the plant to cope with low light stress. From mixed plantation viewpoint, it would be advisable to plant $S$. superba later once the canopy of $C$. lanceolata is well developed but allowing enough sunlight.
\end{abstract}

Keywords: Cunninghamia lanceolate, Light adaptation, Non-structural carbohydrate, Soluble sugar, Starch

\footnotetext{
*Correspondence: liubo@fafu.edu.cn; Mulualem.Tigabu@ess.slu.se; Mulualem.Tigabu@slu.se

${ }^{1}$ Forestry College, Fujian Agriculture and Forestry University, Fuzhou 350002, Fujian, People's Republic of China

Full list of author information is available at the end of the article
} 


\section{Introduction}

Non-structural carbohydrates (NSCs, mainly composed of soluble sugars and starch) are important energy source for all plant growth and metabolism [1, 2]. Soluble sugars are photosynthesis products and are used to meet plant current requirements and osmotic regulation [3]. Starch is the main form of energy stores and is used to meet plants' future needs [1]. NSCs reflect the relationship between $\mathrm{C}$-gain (photosynthesis) and C-loss (respiration and growth) $[4,5]$. NSCs are used to endure periods of negative net carbon balance when plants become suddenly defoliated, shaded, and drought-inflicted [6-10]. So, NSCs play a key role in resisting external adverse environmental stress for plants $[2,6]$. Carbon $(C)$, nitrogen $(\mathrm{N})$ and phosphorus $(\mathrm{P})$ are the basic elements for plant growth and development. The concentrations of $\mathrm{C}, \mathrm{N}, \mathrm{P}$ in plants reflect nutrient uptake, utilization efficiency and adaptation to the environment stress. Higher $\mathrm{N}$ contents are associated with higher leaf area index values, extended photosynthesis duration and greater nutrient uptake [11]. Phosphorus influences photosynthetic assimilation and biomass production in plants [12]. Thus, light intensity affect the leaf photosynthetic capacity, NSC synthesis, and leaf C, N, P content.

Under canopy, light intensity is greatly attenuated before reaching leaf surfaces of seedlings and saplings in the forest understory [13, 14]. Plants have therefore evolved strategies to cope with low light conditions, such as morphological and physiological plasticity, and metabolic adjustments throughout their entire life cycle, especially during the early stages $[15,16]$. Shading is especially frequent in the forest understory, and it is therefore likely that allocation to storage would enhance shade tolerance. Some studies predict that more shade-tolerant species should have higher NSCs concentrations [6]. Previous studies showed that soluble sugars and starch content decreased with increasing shading degree $[6,7]$. However, Munns (1993) showed that soluble sugars and starch content increased with increasing shading degree [17]. As a result, the NSCs content in different light environment are still controversial, and might be species specific. Shading not only affect the photosynthetic capacity, but also affect the activity of carbon and nitrogen fixation related enzymes, and then affect the content of $\mathrm{C}$ and $\mathrm{N}$ in plants [18]. Phosphorus involves in several metabolic process and affects biomass production in plants [19]. Thus, the C:N:P variations in leaves are directly affected by shading degree. In recent years, several studies have tested changes in NSCs, the C:N:P stoichiometry in response to different growth conditions, such as temperature, drought, $\mathrm{CO}_{2}$ concentrations, nitrogen deposition, and phosphorus addition [20-24]. However, few studies have addressed the effects of shade on species in terms of NSCs and C:N: P stoichiometry.
Thus, we investigated the effects of varying levels of shading on leaf morphology, NSCs and C:N:P stoichiometry in Cunninghamia lanceolata (Lamb.) Hook and Schima superba Gardn. \& Champ - the two most important forest species in subtropical China, which are intended for establishment of mixed species forest. C. lanceolata, a fastgrowing, high-yielding tree, is one of the most important plantation tree in China [25]. Like other monocultures, the sustainability of C. lanceolata plantations is threatened by soil degradation, production loss, biodiversity reduction, and a lack of self-regeneration [26-30]. In order to solve this problem, $S$. superba, a broadleaf tree, is increasingly mixed with $C$. lanceolata stands [26, 27, 31, 32]. Previous studies showed that $C$. lanceolate is shade-intolerant tree, in contrast, S. superba is shade-tolerant tree [26]. A shift in preference from monoculture plantations to mixed broadleafconifer plantations has highlighted the need for research on tree development under management-related variation in light environments. Thus, understanding the morphological and physiological responses to light fluctuations should be useful for determining the proper sequence for introducing species in mixed-species plantations during early postplanting.

The objectives of the study were: 1) to examine responses in leaf traits and NSCs contents to different levels of shading between shade-tolerant and shade-intolerant tree species; 2) to investigate the variations in leaf $\mathrm{C}, \mathrm{N}$ and $\mathrm{P}$ contents, and the $\mathrm{C}: \mathrm{N}: \mathrm{P}$ ratio in response to different levels of shading in shade-tolerant and shade-intolerant tree species; 3) to determine the relationships between leaf NSCs, and C:N:P stoichiometry across shading degrees in shade-tolerant and shadeintolerant tree species. We hypothesized that (1) low light conditions (shade) result in larger leaf area but smaller leaf mass per unit area in shade- tolerant ( $S$. superba) than shade-intolerant ( $C$. lanceolata) species so as to acquire more light for photosynthesis under low-light environments - the so called carbon gain hypothesis, (2) NSCs concentrations would be higher in shade-tolerant than shade-intolerant species due to low carbon gain in understory while NSC reserves are needed to enhance shade tolerance; and (3) C:N:P stoichiometry varies with shade levels and the response is species-specific due to differences in photosynthetic efficiency and nutrient absorption. To test these hypotheses, we conducted an experiment by altering light intensity along a gradient to determine the differential effects on leaf morphological traits, NSC content and C:N:P stoichiometry in $C$. lanceolata and S. superba. We also examined variation in soluble sugar and starch contents as well as leaf $\mathrm{C}, \mathrm{N}$, and $\mathrm{P}$ contents. Finally, we looked for potential relationships between leaf NSCs, C:N:P stoichiometry, and their combined effects on plant survival mechanisms. The study will provide valuable insights about optimum light conditions for the establishment and growth of both species under mixed planting scheme. 


\section{Results}

Leaf morphological responses to shade

Leaf traits differed significantly $(P<0.05)$ across shade treatments for each species (Table 1). For S. superba, leaf length, width, and area were the greatest under 85\% shading degree. For C. lanceolata, leaf length, width, and area were the greatest under $60 \%$ shading degree. Leaf mass per unit area was positively correlated with light for both species.

\section{NSCs contents response to shade}

Soluble sugar content, NSC content and soluble sugar/ starch ratio varied significantly across all shade levels in both species (Table 2). Soluble sugar content was higher for C. lanceolata seedlings exposed to 60, 40 and $0 \%$ shading degree than 95 and $85 \%$ shading degree, whereas it was higher for S. superba seedlings exposed to 40 and $0 \%$ shading degree than 95,85 and $60 \%$ shading degree (Fig. 1a). The soluble sugar content was higher for S. superba than C. lanceolata seedlings exposed to 95 and $85 \%$ shading degree. Starch content was higher for S. superba than C. lanceolata across all shade levels, and the highest starch content was observed in seedlings exposed to $40 \%$ shading degree in both species (Fig. 1b). The leaf NSC content was higher in S. superba than in C. lanceolata under all shade levels, and significantly higher under 0, 85 and 95\% shading degree, and in both species NSC content was the highest under $40 \%$ shading degree (Fig. 1c). The soluble sugar to starch ratio was larger for C. lanceolata than S. superba across all levels of shade (Fig. 1d). There was no significant difference in soluble sugar to starch ratio across all levels of shade for S. superba. However, C. lanceolata seedlings exposed to $0 \%$ shading degree had the highest soluble sugar to starch ratio, followed by those exposed to 60 and $40 \%$ shading degree and the least being in 95 and $85 \%$ shading degree.

\section{Leaf C:N:P stoichiometry responses to shade}

Leaf $\mathrm{C}, \mathrm{N}$ and $\mathrm{P}$ contents, as well as $\mathrm{C}: \mathrm{N}: \mathrm{P}$ ratios varied significantly among shade levels in both species. $S$. superba exhibited higher leaf $\mathrm{C}$ content than C. lanceolata (Fig. 2a). In both species, the leaf $\mathrm{N}$ content, contrarily to sugar, NSC, and starch contents that decreased as light reduced, an increasing tendency with increasing shading degree. C. lanceolata had higher leaf $\mathrm{N}$ content than S. superba (Fig. 2b). In both species, the highest leaf $\mathrm{N}$ content was observed in 95\% shading degree compared to other shading degree. Leaf $\mathrm{P}$ content in C. lanceolata showed $70 \%$ drop from no shading treatment $\left(3.13 \pm 0.02 \mathrm{mg} \cdot \mathrm{g}^{-1}\right)$ to $60 \%$ shading degree $(0.93 \pm 0.01$ mg.g ${ }^{-1}$ ) (Fig. 2c). Leaf $\mathrm{P}$ content in S. superba was higher under no shading treatment and $95 \%$ shade degree than under 40, 60 and 85\% shading degree. C. lanceolata exhibited higher leaf P content than S. superba (Fig. 2c). For both species, leaf C:N ratio decreased with increasing shading degree (Fig. 2d), except no shading treatment. Leaf N:P ratio in both species increased with increasing shading degree (Fig. 2e), leaf N:P ratio of $S$. superba was significantly higher than that of $C$. lanceolata. Leaf C:P ratio of $C$. lanceolata reached the maximum at $60 \%$ shading degree, and that of S. superba at $40 \%$ shading degree (Fig. 2f). S. superba had greater leaf C:P ratio than $C$. lanceolata under all shading degree.

\section{Correlations between NSCs contents and C, N, P contents and $\mathrm{C}: \mathrm{N}: \mathrm{P}$ ratio}

Soluble sugar content showed a significantly negative correlation with $\mathrm{N}$ content and $\mathrm{N}: \mathrm{P}$ ratio in both species. Soluble sugar content showed a significantly positive correlation with $\mathrm{C}: \mathrm{N}$ ratio in $C$. lanceolata and showed significantly positive correlation with $\mathrm{C}$ content and $\mathrm{C}: \mathrm{N}$ ratio in S. superba (Table 2). Starch content was significantly negatively correlated with $\mathrm{N}$ content in C. lanceolata, and with $\mathrm{N}$ and $\mathrm{P}$ contents in S. superba. Starch content was positively correlated with $\mathrm{C}: \mathrm{N}$ ratio in $C$. lanceolata, and was positively correlated with $\mathrm{C}$ content, C:N and C:P ratio in S. superba. NSC content positively correlated with $\mathrm{C}$ content, $\mathrm{C}: \mathrm{N}$, and $\mathrm{C}: \mathrm{P}$ ratio, while NSC was negatively related to $\mathrm{N}$ content and N:P ratio in both species. The soluble sugar to starch ratio was positively correlated with $\mathrm{C}$ and $\mathrm{P}$ content, while it had a

Table 1 Leaf traits of Cunninghamia lanceolata and Schima superba in response to different shade degrees

\begin{tabular}{|c|c|c|c|c|c|c|c|c|}
\hline \multirow{2}{*}{$\begin{array}{l}\text { Shading } \\
\text { degree }\end{array}$} & \multicolumn{4}{|c|}{ Cunninghamia lanceolata } & \multicolumn{4}{|c|}{ Schima superba } \\
\hline & $\mathrm{LL}(\mathrm{cm})$ & LW (cm) & $\mathrm{LS}\left(\mathrm{cm}^{2}\right)$ & $\operatorname{LMA}\left(\mathrm{mg} \cdot \mathrm{cm}^{-2}\right)$ & $\mathrm{LL}(\mathrm{cm})$ & LW (cm) & $\mathrm{LS}\left(\mathrm{cm}^{2}\right)$ & LMA $\left(\mathrm{mg} \cdot \mathrm{cm}^{-2}\right.$ \\
\hline $0 \% *$ & $4.44 \pm 0.17 d$ & $0.21 \pm 0.03 b$ & $0.74 \pm 0.02 d$ & $12.75 \pm 0.17 a$ & $8.18 \pm 0.50 c$ & $2.21 \pm 0.18 d$ & $14.91 \pm 0.48 d$ & $11.33 \pm 0.19 a$ \\
\hline $40 \% *$ & $4.67 \pm 0.15 \mathrm{~cd}$ & $0.26 \pm 0.04 a b$ & $0.80 \pm 0.03 \mathrm{~cd}$ & $9.41 \pm 0.10 b$ & $12.65 \pm 0.59 b$ & $2.72 \pm 0.16 c$ & $21.94 \pm 0.71 c$ & $8.32 \pm 0.12 b$ \\
\hline $60 \% *$ & $6.17 \pm 0.14 a$ & $0.30 \pm 0.03 a$ & $1.23 \pm 0.03 a$ & $9.15 \pm 0.14 b$ & $13.49 \pm 0.57 b$ & $3.09 \pm 0.17 b c$ & $22.62 \pm 0.72 c$ & $7.69 \pm 0.12 c$ \\
\hline $85 \% *$ & $5.34 \pm 0.26 b$ & $0.29 \pm 0.02 \mathrm{ab}$ & $0.92 \pm 0.04 b$ & $9.10 \pm 0.25 b$ & $18.29 \pm 0.78 a$ & $3.95 \pm 0.16 a$ & $43.02 \pm 1.82 b$ & $6.43 \pm 0.16 d$ \\
\hline $95 \% *$ & $5.16 \pm 0.22 b c$ & $0.25 \pm 0.02 \mathrm{ab}$ & $0.83 \pm 0.02 c$ & $5.92 \pm 0.10 c$ & $17.20 \pm 0.67 a$ & $3.21 \pm 0.12 b$ & $32.46 \pm 1.51 \mathrm{a}$ & $5.11 \pm 0.08 \mathrm{e}$ \\
\hline
\end{tabular}

Data are represented as means \pm SE. Different lowercase letters indicate significant difference (ANOVA, Tukey's test, $p<0.05$ ) among shade treatments within each species. An asterisk after shading degree indicates significant differences between the two species; $L L$ Leaf length, $L W$ Leaf width, $L S$ Leaf size, $L M A$ Leaf mass per unit area 
Table 2 Correlations between leaf NSCs contents and C, N, P content, and C:N:P ratio of C. lanceolata and S. superba seedlings

\begin{tabular}{|c|c|c|c|c|c|}
\hline \multicolumn{2}{|l|}{ Species } & \multirow{2}{*}{$\frac{\text { Soluble sugar }}{0.443}$} & \multirow{2}{*}{$\frac{\text { Starch }}{-0.136}$} & \multirow{2}{*}{$\begin{array}{l}\text { NSC (Soluble sugar+Starch) } \\
0.371\end{array}$} & \multirow{2}{*}{$\frac{\text { Soluble sugar/Starch }}{\mathbf{0 . 7 6 8}^{* *}}$} \\
\hline C. lanceolata & C & & & & \\
\hline & $N$ & $-0.879^{* *}$ & $-0.788^{* *}$ & $-0.903^{* *}$ & $-0.477^{*}$ \\
\hline & $P$ & 0.248 & -0.319 & 0.168 & $0.663^{*}$ \\
\hline & $C: N$ & $0.898^{* *}$ & $0.841^{* *}$ & $0.929^{* *}$ & 0.443 \\
\hline & $N: P$ & $-0.731^{* *}$ & -0.282 & $-0.692^{* *}$ & $-0.762^{* *}$ \\
\hline & $C: P$ & -0.023 & 0.407 & 0.045 & -0.434 \\
\hline \multirow[t]{6}{*}{ S. superba } & $C$ & $0.555^{*}$ & $0.539^{*}$ & $0.587^{* *}$ & 0.024 \\
\hline & N & $-0.820^{* *}$ & $-0.774^{* *}$ & $-0.860^{* *}$ & -0.082 \\
\hline & $P$ & -0.242 & $-0.497^{*}$ & -0.339 & 0.330 \\
\hline & $C: N$ & $0.781^{* *}$ & $0.735^{* *}$ & $0.819^{* *}$ & 0.080 \\
\hline & $N: P$ & $-0.725^{* *}$ & -0.436 & $-0.681^{* *}$ & -0.402 \\
\hline & $C: P$ & 0.341 & $0.583^{* *}$ & 0.441 & -0.306 \\
\hline
\end{tabular}

Date are Pearson correlation coefficients. **Significant at $p<0.01,{ }^{*}$ significant at $p<0.05$

negative correlation with $\mathrm{N}$ content and $\mathrm{N}: \mathrm{P}$ ratio in $C$. lanceolata.

\section{Discussion}

The considerable variation in leaf morphology and structure reflects the organ's phenotypic plasticity [33]. Therefore, leaf characteristics are often used as an indicator of plant acclimation potential and adaptation mechanism [34]. Because excessive irradiance has a detrimental impact on photosynthetic tissues, plants must produce smaller and thicker leaves with higher leaf mass per area under high light conditions. This morphology allows heat dissipation, avoiding damage from overheating and high transpiration rates $[35,36]$. Conversely, shaded conditions result in increasing area and decreasing thickness of leaves [26, 37], with low leaf mass per unit area [38]. Increasing leaf area allows plants to acquire more light for photosynthesis [13,39] and is thus an adaptation to low-light environments [36]. In this study, we observed larger leaf area under $85 \%$ shading degree for S. superba and under $60 \%$ shading degree for C. lanceolata. Our findings are in line with previous research on Elaeagnus angustifolia leaves, which became smaller and thicker under high light intensity [36].

Furthermore, leaf mass per unit area (LMA) decreased with increasing shading degree in both species. In agreement with our results, Alocasia macrorrhiza displays the same adaptations (larger and thinner leaves) to optimize photosynthetic efficiency under low light availability [40]. Shading also resulted in greater LMA for Citharexylum, Dendropanax, Fraxinus, Quercus, and Magnolia [41]. Interestingly, our study revealed between-species differences in the response of mean leaf area to increasing shading degree. Specifically, mean leaf area was greatest at $60 \%$ shading degree in C. lanceolata, but at $85 \%$ shading degree in S. superba. These traits enhanced the ability of $S$. superba to tolerate low light condition (shading) compared with C. lanceolata, which concords with a previous study [42]. Our finding is in line with the carbon gain hypothesis that leaf area is higher in shade-tolerant seedlings than in shade-intolerant seedlings [43], and implies that $S$. superba is better adapted to shading.

C. lanceolata seedlings have been shown to adapt to shaded conditions through adjusting morphological characteristics [44]. However, seedlings had difficulty maintaining $C$ balance under extremely shaded $(95 \%$ shading degree) conditions, causing poor growth and survival. The issue of negative $C$ and relatedly NSCs balance under low light is a common problem plants face. For instance, a study made on Pinus koraiensis and Quercus mongolica demonstrated that low light induced carbohydrate deficiency and therefore high seedling mortality, with none surviving at $1 \%$ light intensity [6]. Similarly, under extremely shaded conditions, Quercus aliena seedlings had difficulty maintaining $C$ balance and thus experienced mortality [45]. To overcome the lack of an energy source under low light intensity, plants store NSCs to enhance growth and survival $[6,7,24,38]$. Here, we found that $40 \%$ shading degree results in significantly higher soluble sugar, starch, and NSC content for both species. Once under low light intensity, all three variables decreased, presumably as a result of seedlings using their energy stores for growth and also a decrease in $C$ fixation due to light limitation.

Shade-tolerant species should have higher NSCs concentrations than shade-intolerant species [7], because carbon gain was low in understory and NSC reserves are needed to enhance shade tolerance. Other studies also found that shade-tolerant species tend to have greater NSC reserves. For example, the seedlings of palm Chamaedora elegans (shade-tolerant species) had 


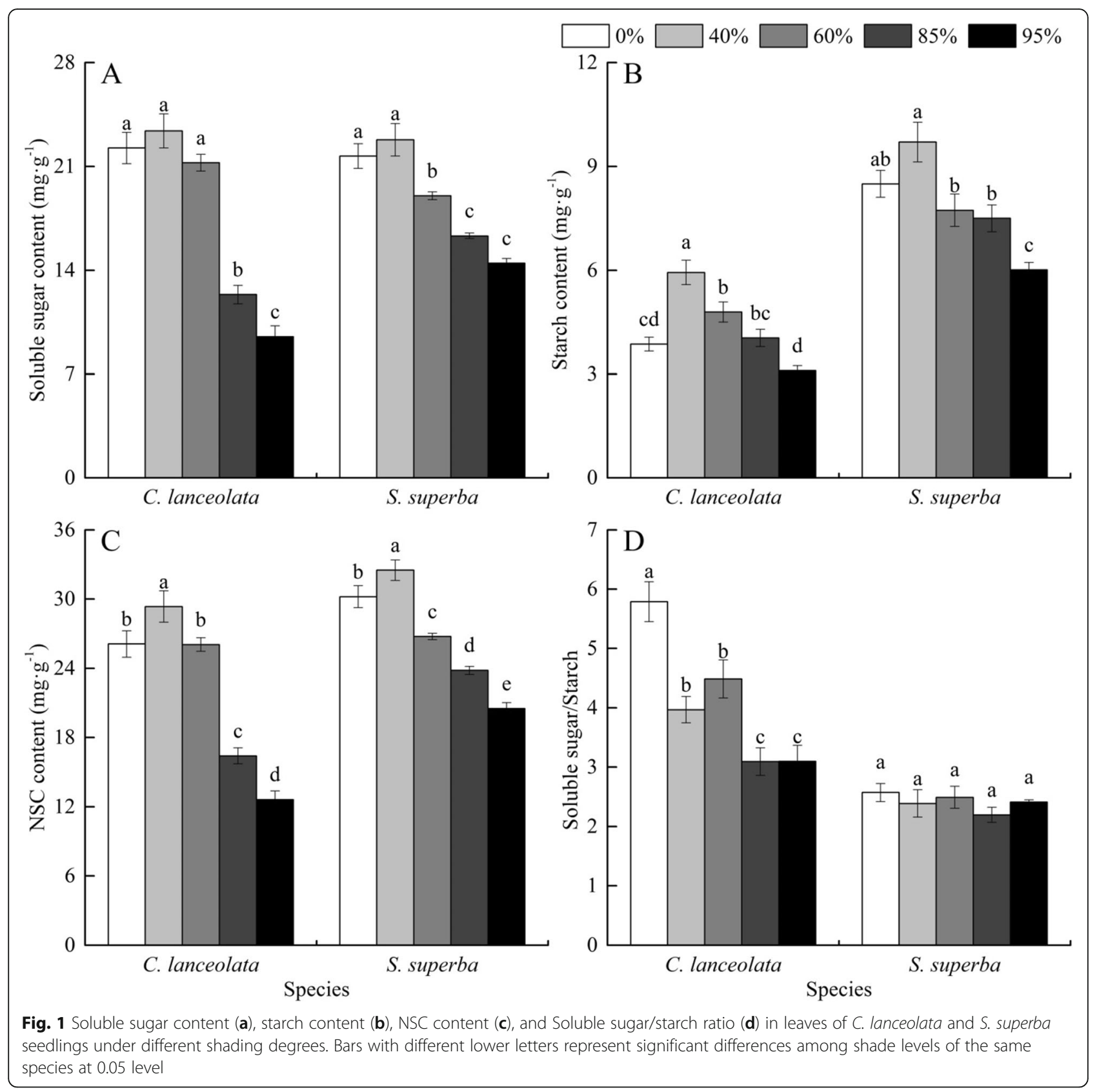

higher NSC content than seedling of Chrysalidocarpus lutescens (shade-intolerant species) [46, 47]; and the shade-tolerant species Acer saccharum seedlings had higher NSC concentrations than seedlings of intermediate light-demanding Betula alleghaniensis [48]. In our study, seedlings of shade-tolerant S. superba had higher NSC content than shade-intolerant C. lanceolate, especially under low light conditions. This result demonstrates that $S$. superba seedlings had an advantage under shaded conditions and, moreover, could flexibly adjust to a vast range of shade levels. In terms of mechanism, exposure to high light intensity would result in greater $\mathrm{C}$ gain than demand, leading to NSCs storage [38, 49]. Once light becomes a limiting resource, plants will mobilize NSCs to support growth and survival [50]. Under $85 \%$ shading, growth in height, diameter and biomass production of $S$. superba were considerable higher than other shading treatments (Data not shown). The results support our hypothesis that $S$. superba produces more NSCs under low light condition than $C$. lanceolata. This finding agrees with a previous study that demonstrated that shade-tolerant 

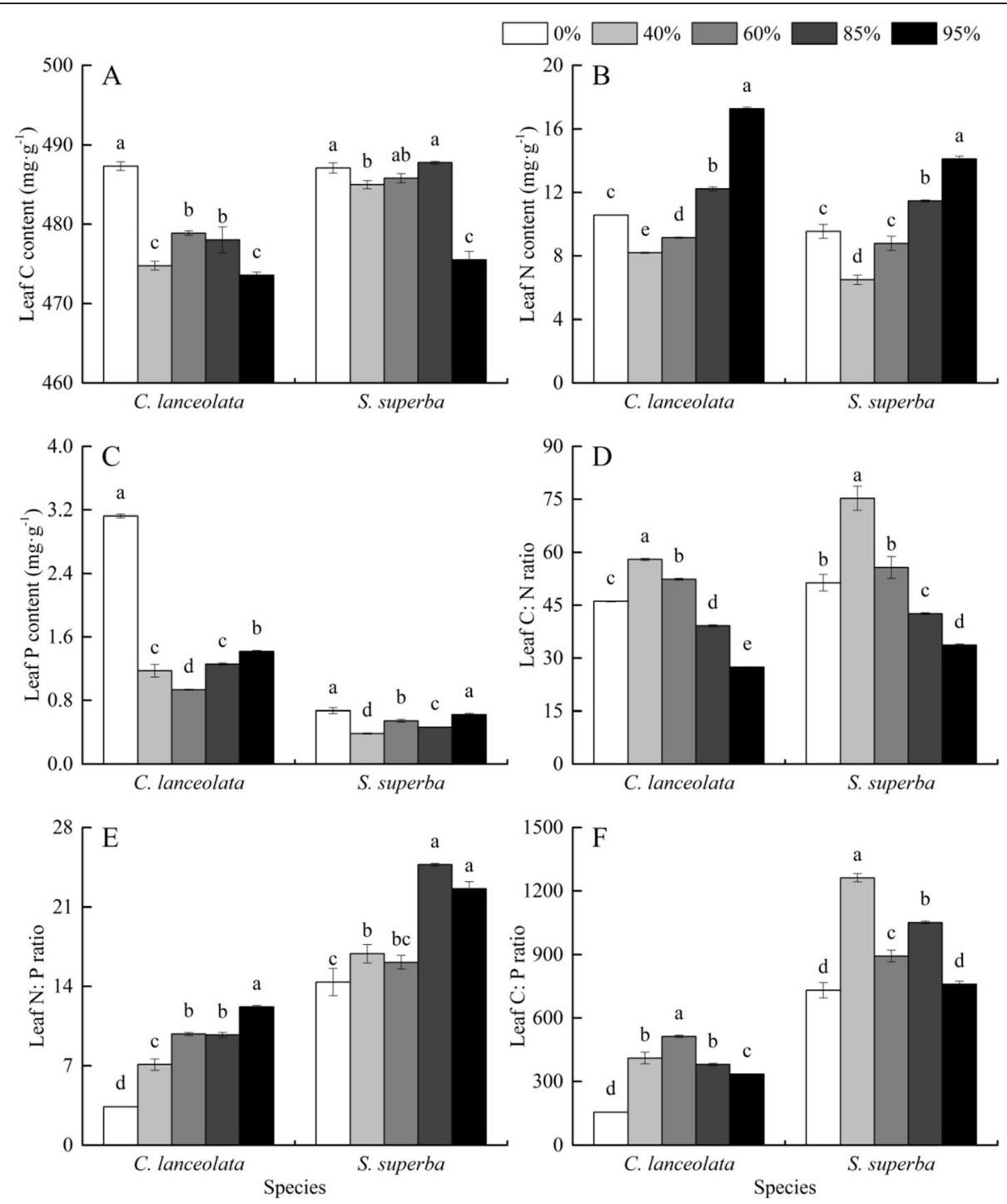

Fig. 2 C content (a), N content (b), P content (c), C:N ratio (d), N:P ratio (e), C:P ratio (f) in leaves of C. lanceolata and S. superba seedlings under different shading degrees. Bars with different lower letters represent significant differences among shade levels of the same species at 0.05 level

species exhibit higher NSCs content than shadeintolerant species [7].

Both genetic and environmental factors influence plant nutrient uptake, as demonstrated by interspecific differences, along with intraspecific differences under various habitats [51]. In our study, S. superba and C. lanceolata produce $\mathrm{C}$ during photosynthesis and absorb $\mathrm{N}$ and $\mathrm{P}$ differently under varying shading degree, suggesting species-specific strategies in balancing nutritional metabolism and adapting to environmental stress. Both species had higher $\mathrm{C}$ content under intermediate shade condition $(40-60 \%$ to full light availability), likely due to strong photosynthetic efficiency resulting in heightened synthesis of organic matter and $C$ accumulation. Importantly C content was significantly larger in S. superba than in C. lanceolata. Given previous research linking higher $\mathrm{C}$ content with greater photosynthetic efficiency and resilience to adverse environments [52], our findings imply that $S$. superba is better adapted to low light condition than $C$. lanceolata. Our results are consistent with previous studies demonstrating that shade-tolerant plants have higher NSCs accumulation and C pool than shade-intolerant plants [7, 24], this is because their photosynthetic machinery is adapted to be more efficient in the low light condition and store more $\mathrm{C}$ than plants that are not adapted their photosystems to low light. Higher $\mathrm{P}$ and $\mathrm{N}$ contents in both species were observed under no shading treatment and 95\% shading degree, respectively. These results support that the adaptive strategy to shade might be species specific. $\mathrm{P}$ and $\mathrm{N}$ are essential macro-elements for plant growth and development, which participate in a number of metabolic 
processes, such as photosynthetic phosphorylation, ATP production, the production and export of triose-P and ribulose-1, 5-bisphosphate regeneration as well as synthesis of amino acids [53]. This outcome is the vigorous growth under strong photosynthetic ability in full sunlight, leading to greater requirements for proteins and nucleic acids. On the contrary, seedlings of both species may use more $\mathrm{N}$ resources to synthesize light-trapping proteins under low light intensity. This is further evidenced in our study that NSC content was negatively correlated with $\mathrm{N}$ content and $\mathrm{N}: \mathrm{P}$ ratio in both species, whereas a positive correlation was observed between NSC and C:N ratio in C. lanceolata and with C content and $\mathrm{C}: \mathrm{N}$ ratio in S. superba. Our findings are corroborated by previous research showing that plants growing under low light condition will have increased leaf $\mathrm{N}$ content and allocate more $\mathrm{N}$ to photosynthetic pigments. We observed higher chlorophyll a content in S. superba than in C. lanceolata (data not shown). Due to the prevention of photo-damage, this strategy increases light use efficiency and maintain normal photosynthetic function [54]. The findings give credence to our results that $\mathrm{C}: \mathrm{N}: \mathrm{P}$ stoichiometry varies with shade levels might be species-specific. As a whole, the findings have greater implication for establishment and maintenance of mixed species stand. S. superba is better adapted to low light intensity (shade tolerant), thus it would be advisable to plant $S$. superba later once the canopy of $C$. lanceolata is well developed but allowing enough sunlight (up to 40\%). Conversely, thinning of dense stands of C. lanceolata to allow sufficient light to reach the understory would be recommended to expedite the natural regeneration and subsequent growth of S. superba.

\section{Conclusions}

The results demonstrate that shading significantly affected foliage morphology, leaf NSC content, and C, N, $\mathrm{P}$ stoichiometry in shade-intolerant species C. lanceolata and shade-tolerant species S. superba seedlings. In general, both species showed a decrease in NSC, soluble sugar and starch content with increasing shading degree. However, S. superba had higher NSC content than $C$. lanceolate, especially under low light conditions. These results imply a decrease in photosynthesis efficiency in C. lanceolata with increasing shading and suggest that carbohydrate storage is especially important for species that regenerate in persistently shady habitats. Highly significant correlations were found between leaf NSC variables and $\mathrm{C}, \mathrm{N}, \mathrm{P}$ content and C:N:P ratio in $C$. lanceolate and S. superba. It was likely that the dynamic trade-off of photosynthesis products exists between leaf NSCs and C:N:P stoichiometry. Our results improve our understanding of the balance of leaf $\mathrm{C}, \mathrm{N}, \mathrm{P}$ components and NSCs contents in shade-tolerant and shade- intolerant plants. In addition, the findings have greater implication for establishment of mixed species stand. As S. superba is better adapted to low light condition (shade tolerant), it would be advisable to plant $S$. superba later once the canopy of $C$. lanceolata is well developed but allowing enough sunlight (up to 40\% light transmittance). Conversely, in dense stands of C. lanceolata, thinning to allow sufficient light to reach the understory would be recommended to expedite the natural regeneration and subsequent growth of S. superba as we observed better growth of $S$. superba under low light condition.

\section{Materials and methods}

\section{Experimental design and treatments}

The pot experiment was conducted in a flat, open area at the Fujian Agriculture and Forestry University. Five shade levels were created, i.e., $0 \%$ (control, no-shading), $40 \%$ shaded (60\% irradiance), $60 \%$ shaded ( $40 \%$ irradiance), $85 \%$ shaded (15\% irradiance), $95 \%$ shaded (5\% irradiance). Each shading degree was created using frame covered with black nylon shade cloth of differing mesh size $(0 \%$ shaded did not use shade cloth) [55]. The frames were $2.0 \mathrm{~m}$ high, $6.0 \mathrm{~m} \times 2.5 \mathrm{~m}$ in length and width, and were placed parallel to the sun's daily track to minimize spatiotemporal variation in solar radiation. The light intensity in each shading degree treatment was measured with two light meters (Hipoint HP350, Taiwan, China, and Red/Far-red Sensor, Skye Instruments Ltd., UK) during clear day (see Appendix S1).

In July 2016, C. lanceolata and S. superba seedlings were purchased from a container nursery in Zhangping Wuyi Forest Farm, Fujian, China. Purchased seedlings were transplanted to pots containing a mixture of peat soil and vermiculite $(2: 1 \mathrm{w} / \mathrm{w})$ and were grown for 1 month in a greenhouse at the experimental site. Fertilizer was not added during the experiment period. In August 2016, welldeveloped seedlings of uniform height (C. lanceolata: $18.49 \pm 1.97 \mathrm{~cm}$, S. superba: $27.40 \pm 1.19 \mathrm{~cm}$ ) were selected and randomly divided into five groups. Each group comprised four seedlings per species and was assigned to each of shading degree treatment. Individual seedling pots were treated as replicates and randomly positioned to ensure each obtained similar light irradiation with no mutual shading. Pots were rotated weekly to ensure homogeneous conditions. Weeds were periodically cleared from the experimental plot and seedlings were watered 2-3 times weekly.

\section{Leaf morphology measurements}

All plants were maintained under their assigned shade levels for $1 \mathrm{y}$. To estimate mean leaf area, 10 healthy and fully expanded green leaves were randomly collected from seedlings of comparable height in the same pot. In order to keep the leaves fresh, leaf samples were placed 
in ice and immediately taken to the laboratory for further analysis. Individual leaf area $\left(\mathrm{cm}^{2}\right)$ was determined with a portable leaf area meter (Yaxin-1241, Shanghai, China). Leaves were then individually placed in paper bags and oven-dried for $30 \mathrm{~min}$ at $105^{\circ} \mathrm{C}$, followed by at least $24 \mathrm{~h}$ at $80^{\circ} \mathrm{C}$. Upon reaching a constant dry mass, the dry mass of each leaf was determined. Leaf mass per unit area (LMA, mg. $\mathrm{cm}^{-2}$ ) was computed as the ovendry mass per leaf divided by the corresponding area.

\section{Measurements of NSCs}

At the end of the experiment in August 2017, leaves were randomly collected from seedlings of both species across all shade treatments, cleaned with distilled water, and grounded to powder. $0.2 \mathrm{~g}$ of the ground sample were mixed with $5 \mathrm{~mL}$ of distilled water in a test tube. After $30 \mathrm{~min}$ in a boiling water bath, the supernatant was collected. This process was repeated twice to ensure complete sugar extraction. The two extracts were collected in a centrifuge tube and distilled water was then added to achieve a $25 \mathrm{~mL}$ constant volume. Thereafter, sediments from the soluble sugar extraction were dried and then the perchloric acid was added to extract starch. Soluble sugar and starch contents were determined using the anthrone colorimetric method. Absorbance at $630 \mathrm{~nm}$ was measured to calculate soluble sugar and starch contents according to the glucose standard curve. Non-structural carbohydrates content was calculated as the sum of soluble sugar and starch content. The analysis was replicated four times per treatment.

\section{Measurements of leaf $C, N, P$}

At the end of the experiment, all leaves of the same replicate seedling under the same treatment were collected, and then grounded into uniformly fine powder, and sieved with a $1 \mathrm{~mm}$ mesh before chemical analysis. Total $\mathrm{C}$ and $\mathrm{N}$ content (mg.g ${ }^{-1}$, dry mass basis) were measured via dry combustion using an elemental analyzer (VARIO MAX CN; Elementary, Germany). Total P concentration $\left(\mathrm{mg} \cdot \mathrm{L}^{-1}\right)$ was determined with ICP-OES (Optima 8000, PerkinElmer) after $\mathrm{H}_{2} \mathrm{SO}_{4}-\mathrm{HClO}_{4}$ solution digestion and dilution. After converting to $\mathrm{mg} \cdot \mathrm{g}^{-1}$, the C:N, C:P and N:P ratios were calculated as content ratio. All chemical analyses were replicated four times per light treatment and species.

\section{Statistical analysis}

One-way ANOVA was performed for each species separately to test the significant effect of shading on leaf morphology, NSCs contents, and C, N, P content, and $\mathrm{C}: \mathrm{N}: \mathrm{P}$ stoichiometry. Pearson's correlation analysis was performed to examine the relationship between NSCs contents, and C, N, P content and C:N:P ratio. Data are presented as means \pm SE for different shade treatments and species. Statistical significance was set at $p<0.05$. All statistical analyses were performed in SPSS version 20.0 for Windows (SPSS Inc., Chicago, IL, USA).

\section{Supplementary information}

Supplementary information accompanies this paper at https://doi.org/10. 1186/s12870-020-02556-4.

Additional file 1: Appendix S1. Light conditions in different shade treatments (mean $\pm \mathrm{SE}$ ). Different letters indicate significant differences in light conditions across shade treatments.

Additional file 2.

\section{Abbreviations}

NSC: Non-structural carbohydrate; C: Carbon; N: Nitrogen; P: Phosphorus; LMA: Leaf mass per unit area; LL: Leaf length; LW: Leaf width; LS: Leaf size

\section{Acknowledgments}

We would like to thank Editage [http://online.editage.cn/] for English language editing during the preparation of this manuscript.

\section{Authors' contributions}

BL conceived the study. BL and QQL designed the experiments. QQL, ZJH, YFC, and ZMW performed the experiments. QQL and BL analysed the data. $\mathrm{QQL}, \mathrm{BL}$ and MT wrote the manuscript. All authors read and approved the final manuscript.

\section{Funding}

This work was supported by the National Natural Science Foundation of China (grant numbers 31670714, 31570448). The funding provided the financial support to the research projects, but did not involve in project design, data collection, analysis, or preparation of the manuscript. Open access funding provided by Swedish University of Agriculture Sciences.

Availability of data and materials

Data are made available as supplementary material.

Ethics approval and consent to participate Not applicable.

Consent for publication

Not applicable.

\section{Competing interests}

The authors declare that they have no competing interests.

\section{Author details}

${ }^{1}$ Forestry College, Fujian Agriculture and Forestry University, Fuzhou 350002, Fujian, People's Republic of China. ${ }^{2}$ Fujian Provincial Colleges and University Engineering Research Center of Plantation Sustainable Management, Fuzhou 350002, Fujian, People's Republic of China. ${ }^{3}$ Southern Swedish Forest Research Center, Faculty of Forest Science, Swedish University of Agricultural Sciences, PO Box 49, SE-230 53 Alnarp, Sweden.

Received: 17 February 2020 Accepted: 19 July 2020

Published online: 29 July 2020

References

1. Hartmann H, Trumbore S. Understanding the roles of nonstructural carbohydrates in forest trees-from what we can measure to what we want to know. New Phytol. 2016;211:386-403.

2. O'Brien MJ, Leuzinger S, Philipson CD, Tay J, Hector A. Drought survival of tropical tree seedlings enhanced by nonstructural carbohydrate levels. Nat Clim Chang. 2014;4:710-4.

3. Dietze MC, Sala A, Carbone MS, Carbone MS, Czimczik Cl, Mantooth JA, Richardson AD, Vargas R. Nonstructural carbon in woody plants. Annu Rev Plant Biol. 2014;65:667-87. 
4. Yang QP, Zhang WD, Li RS, Xu M, Wang SL. Different responses of nonstructural carbohydrates in above-ground tissues/organs and root to extreme drought and re-watering in Chinese fir (Cunninghamia lanceolata) saplings. Trees-Struct Funct. 2016;30:863-1871.

5. Richardson AD, Carbone MS, Huggett BA, Furze ME, Czimczik Cl, Walker JC, Xu XM, Schaberg PG, Murakami P. Distribution and mixing of old and new nonstructural carbon in two temperate trees. New Phytol. 2015:206:590-7.

6. Zhang M, Zhu JJ, Li MC, Zhang GQ, Yan QL. Different light acclimation strategies of two coexisting tree species seedlings in a temperate secondary forest along five natural light levels. Forest Ecol Manag. 2013;306:234-42.

7. Poorter L, Kitajima K. Carbohydrate storage and light requirements of tropical moist and dry forest tree species. Ecology. 2007;88:1000-11.

8. Piper Fl, Reyes-Díaz M, Corcuera L, Lusk CH. Carbohydrate storage, survival, and growth of two evergreen Nothofagus species in two contrasting light environments. Ecol Res. 2009;24:1233-41.

9. Piper Fl. Drought induces opposite changes in the concentration of nonstructural carbohydrates of two evergreen Nothofagus species of differential drought resistance. Ann Forest Sci. 2011;68:415-24.

10. Regier N, Streb S, Cocozza C, Schaub M, Cherubini P, Zeeman SC, Frey B. Drought tolerance of two black poplar (Populus nigra L.) clones: contribution of carbohydrates and oxidative stress defence. Plant Cell Environ. 2009;32:1724-36.

11. He MZ, Zhang K, Tan HJ, Hu R, Su JQ, Wang J, Huang L, Zhang YF, Li XR. Nutrient levels within leaves, stems, and roots of the xeric species Reaumuria soongorica in relation to geographical, climatic, and soil conditions. Ecol Evol. 2015;5:1494-503.

12. Vrede T, Dobberfuhl DR, Elser JJ. Fundamental connections among organism C:N:P stoichiometry, macromolecular composition, and growth. Ecology. 2004:85:1217-29.

13. Lambers H, Chapin FS III, Pons TL. Plant Physiological Ecology. New York: Springer Science \& Business Media; 2008.

14. Gandolfi S, Joly CA, Leitão Filho HF. "gaps of deciduousness": cyclical gaps in tropical forests. Sci Agrár. 2009;66:280-4.

15. Nicotra AB, Atkin OK, Bonser SP, Davidson AM, Finnegan EJ, Mathesius U, Poot P, Purugganan MD, Richards CL, Valladares F, van Kleunen M. Plant phenotypic plasticity in a changing climate. Trends Plant Sci. 2010;15:684-92.

16. Jafari T, Rahikainen M, Puljula E, Sinkkonen J, Kangasjärvi S. The impact of light intensity on metabolomic profile of Arabidopsis thaliana wild type and reticulata mutant by NMR spectroscopy. Phytochem Lett. 2018;26:170-8.

17. Munns R. Physiological processes limiting plant growth in saline soils: some dogmas and hypotheses. Plant Cell Environ. 1993;16:15-24.

18. Dickman EM, Newell JM, González MJ, Vanni MJ. Light, nutrients, and foodchain length constrain planktonic energy transfer efficiency across multiple trophic levels. P Natl Acad Sci. 2008;105:18408-12.

19. Yang XJ, Huang ZY, Zhang KL, Cornelissen JH. C:N:P stoichiometry of Artemisia species and close relatives across northern China: unravelling effects of climate, soil and taxonomy. J Ecol. 2015;103:1020-31.

20. Villarsalvador P, Uscola M, Jacobs DF. The role of stored carbohydrates and nitrogen in the growth and stress tolerance of planted forest trees. New For. 2015;46:813-39.

21. Henry HAL, Chiariello NR, Vitousek PM, Mooney HA, Field CB. Interactive effects of fire, elevated carbon dioxide, nitrogen deposition, and precipitation on a California annual grassland. Ecosystems. 2006;9:1066-75.

22. Li WB, Hartmann H, Adams HD, Zhang HX, Jin CJ, Zhao CY, Guan DX, Wang $\mathrm{AZ}$, Yuan FH, Wu JB. The sweet side of global change-dynamic responses of non-structural carbohydrates to drought, elevated $\mathrm{CO}_{2}$ and nitrogen fertilization in tree species. Tree Physiol. 2018;38:1706-23.

23. Von AG, Arzac A, Fonti P, Frank D, Zweifel R, Rigling A, Galiano L, Gessler A, Miguel Olano J. Responses of sapwood ray parenchyma and non-structural carbohydrates of Pinus sylvestris to drought and long-term irrigation. Funct Ecol. 2017;31:1371-82.

24. Myers J, Kitajima K. Carbohydrate storage enhances seedling shade and stress tolerance in a neotropical forest. J Ecol. 2007;95:383-95.

25. Yang YS, Wang LX, Yang ZJ, Xu C, Xie JS, Chen GS, Lin CF, Guo JF, Liu XF, Xiong DC, Lin WS, Chen SD, He ZM, Lin KM, Jiang MH, Lin TC. Large ecosystem service benefits of assisted natural regeneration. J Geophys Res. 2018;123:676-87.

26. Liu B, Liu QQ, Daryanto S, Guo S, Huang ZJ, Wang ZN, Wang LX, Ma XQ. Responses of Chinese fir and Schima superba seedlings to light gradients: implications for the restoration of mixed broadleaf-conifer forests from Chinese fir monocultures. Forest Ecol Manag. 2018;419:51-7.

27. Chen LC, Wang SL, Wang P, Kong CH. Autoinhibition and soil allelochemical (cyclic dipeptide) levels in replanted Chinese fir (Cunninghamia lanceolata) plantations. Plant Soil. 2014;374:793-801.

28. Luo J, Tian YX, Zhou XL, Chen JH, Zeng ZQ, Li XQ, Yao M. Studies on the characteristics of soil seed banks under main forest types of close-to-nature forest management in Hunan. J Cent South Univ For Technol. 2014;34:56-61.

29. $M a X Q$, Heal KV, Liu AQ, Jarvis $P G$. Nutrient cycling and distribution in different-aged plantations of Chinese fir in southern China. For Ecol Manag. 2007;243:61-74

30. Yang YS, Guo JF, Chen GS, Xie JS, Cai LP, Lin P. Litterfall, nutrient return, and leaf-litter decomposition in four plantations compared with a natural forest in subtropical China. Ann Forest Sci. 2004;61:465-76.

31. Huang $Y$, Wang SL, Feng ZW, Ouyang ZL, Wang XK, Feng ZZ. Changes in soil quality due to introduction of broad-leaf trees into clear-felled Chinese fir forest in the mid-subtropics of China. Soil Use Manag. 2004;20:418-25.

32. Xiong HB. Study on variation of the properties of soil in multi-storied Chinese fir plantation. Subtrop Agric Res. 2007;4:283-6.

33. Chen FS, Zeng DH, Fahey TJ, Yao CY, Yu ZY. Response of leaf anatomy of Chenopodium acuminatum to soil resource availability in a semi-arid grassland. Plant Ecol. 2010;209:375-82.

34. Carlson JE, Adams CA, Holsinger KE. Intraspecific variation in stomatal traits, leaf traits and physiology reflects adaptation along aridity gradients in a south African shrub. Ann Bot London. 2015;117:195-207.

35. Nascimento KC, Pastorini LH, Romagnolo MB, de Souza LA. Do Eugenia hiemalis seedling leaves under different light conditions develop phenotypic plasticity? Plant Ecol. 2015;216:1571-81.

36. Klich MG. Leaf variations in Elaeagnus angustifolia related to environmental heterogeneity. Environ Exp Bot. 2000;44:171-83.

37. Sevillano I, Short I, Grant J, O'Reilly C. Effects of light availability on morphology, growth and biomass allocation of Fagus sylvatica and Quercus robur seedlings. Forest Ecol Manag. 2016;374:11-9.

38. Valladares F, Niinemets Ü. Shade tolerance, a key plant feature of complex nature and consequences. Annu Rev Ecol Evol S. 2008;39:237-57.

39. Matyssek R, Fromm J, Rennenberg H, Roloff A. Biologie der Bäume: von derZelle zur globalen Ebene. UTB. 2010, P8450, 349 pp.

40. Franklin KA. Shade avoidance. New Phytol. 2008;179:930-44.

41. Saldana-Acosta A, Meave JA, Sanchez-Velasquez LR. Seedling biomass allocation and vital rates of cloud forest tree species: responses to light in shade house conditions. Forest Ecol Manag. 2009;258:1650-9.

42. Liu N, Guo QF, Ren H, Sun ZY. Schima superba outperforms other tree species by changing foliar chemical composition and shortening construction payback time when facilitated by shrubs. Sci Rep-UK. 2016;6:19855.

43. Givnish TJ. Adaptation to sun and shade: a whole-plant perspective. Funct Plant Biol. 1988;15:63-92.

44. Liu QQ, Ma XQ, Huang ZJ, Guo S, Wang DY, Wang CH, Liu B. Effects of light intensity on the morphology characteristics and leaf non-structural carbohydrate content of Chinese fir seedlings. Acta Ecol Sin. 2019;39:4455-62.

45. Chen ZC, Liu XJ, Liu C, Wan XC. Responses of growth, photosynthesis and nonstructural carbohydrate of Quercus aliena var. acuteserrata seedlings to shading and simulated sunfleck. Chinese J Ecol. 2017;36:935-43.

46. Reyes T, Nell TA, Barrett JE, Conover CA. Irradiance level and fertilizer rate affect acclimatization of Chamaedorea elegans Mart. Hortence. 1996;31:839-42.

47. Reyes T, Nell TA, Barrett JE, Conover CA. Testing the light acclimatization of Chrysalidocarpus lutescens Wendl. Hortscience. 1996;31:1203-6.

48. Gaucher C, Gougeon S, Mauffette Y, Messier C. Seasonal variation in biomass and carbohydrate partitioning of understory sugar maple (Acer saccharum) and yellow birch (Betula alleghaniensis) seedlings. Tree Physiol. 2005;25:93-100.

49. Chapin IIIFS, Schulze ED, Mooney HA. The ecology and economics of storage in plants. Annu Rev Ecol Evol S. 1990;21:423-47.

50. Iwasa Y, Kubo T. Optimal size of storage for recovery after unpredictable disturbances. Evol Ecol. 1997;11:41-65.

51. Ma ZL, Gao S, Yang WQ, Zhu P, Wu FZ, Tan B. Effects of shading treatments on biomass and nutrient accumulation of herb community in abandoned land in the subtropical region. Acta Ecol Sin. 2015;35:5279-86.

52. Wright IJ, Reich PB, Westoby M, Ackerly DD, Baruch Z, Bongers F, CavenderBares J, Chapin T, Cornelissen JHC, Diemer M, Flexas J, Garnier E, Groom PK, Gulias J, Hikosaka K, Lamont BB, Lee T, Lee W, Lusk C, Midgley JJ, Navas ML, Niinemets Ü, Oleksyn J, Osada N, Poorter H, Poot P, Prior L, Pyankov VI, 
Roumet C, Thomas SC, Tjoelker MG, Veneklaas EJ, Villar R. The worldwide leaf economics spectrum. Nature. 2004;428:821.

53. Warren CR. How does $P$ affect photosynthesis and metabolite profiles of Eucalyptus globulus? Tree Physiol. 2011;31:727-39.

54. Evans JR, Poorter H. Photosynthetic acclimation of plants to growth irradiance: the relative importance of specific leaf area and nitrogen partitioning in maximizing carbon gain. Plant Cell Environ. 2001;24:755-67.

55. Liu B, Liu QQ, Daryanto S, Ma XQ, Guo S, Wang LX, Wang ZN. Seedling emergence and early growth of Chinese fir under different light levels and seed positions: implications for natural regeneration. Can J For Res. 2018:48: 1034-41.

\section{Publisher's Note}

Springer Nature remains neutral with regard to jurisdictional claims in published maps and institutional affiliations.

Ready to submit your research? Choose BMC and benefit from:

- fast, convenient online submission

- thorough peer review by experienced researchers in your field

- rapid publication on acceptance

- support for research data, including large and complex data types

- gold Open Access which fosters wider collaboration and increased citations

- maximum visibility for your research: over $100 \mathrm{M}$ website views per year

At BMC, research is always in progress.

Learn more biomedcentral.com/submissions 